\title{
Fiestas y celebraciones cívico- religiosas en la Barcelona Constitucional (1820-1823)
}

\author{
YOSHIKO YAMAMICHI
}

\begin{abstract}
RESUMEN
Se intenta estudiar las fiestas y celebraciones cívico-religiosas de

Barcelona durante el Trienio

Constitucional con el motivo de

acercarse a la mentalidad, la
\end{abstract} religiosidad y la cultura de los liberales, tanto de los dirigentes corno del pueblo de dicha ciudad, utilizando como fuente principal un diario de un zapatero que se llama Mateu Crespi. Se estudian las fiestas liberales desde el punto de vista de tipos de celebraciones, de su simbología, y de los lugares donde se celebraban las fiestas, además de la decadencia de las fiestas tradicionales

y la frecuencia de rogativas y otros ritos con causas inesperadas. A través

de sus estudios se advertirá que los liberales de dicho período celebraron muchas fiestas para animar e instruir al pueblo, y que en sus celebraciones se mezclaban unas características nuevas

y otras que heredaban el pasado. $E$ igualmente se notará su mentalidad e ideas que no serían compatibles con el

liberalismo centralista, tales como la tendencia de los dirigentes o el ansia

\section{ABSTRACT}

The purpose of this presentation is to examine festivals and other acts of Barcelona during the three years of liberal regim (1820-1823), to analyze the mentality, religiosity, and culture of the liberals, not only its leaders but also the people of the city of Barcelona. The reporter examines the decadence of traditional festivals, some characteristics of the liberal festivales (tipes of celebrations, its symbology, and places of the acts), and the frequency of rogation and other rites. It could be concluded that the liberals of Barcelona organized many festivals to encourage and to instruct the people, and that some aspects of the liberal festivals were new, but other aspects inherited the past. And also we can see some caracteristics that would no be compatible with the oficial liberalism, such as a romantic tendency of the leaders and desire of the people to continue with their traditional symbols. 
del pueblo por continuar con los símbolos tradicionales.

PALABRAS CLAVE

Barcelona, Trienio Constitucional, fiesta, liberalismo, mentalidad, religiosidad.
KEY WORD

Barcelona, "Trienio Constitucional", festival, liberalism, mentality, religiosity.

\section{INTRODUCCIÓN}

¿Hasta qué punto la sociedad del antiguo régimen era una sociedad clericalizada? Es una pregunta difícil de contestar que encontramos en la obra de Dufour ${ }^{1}$. Aparte de la omnipresencia de la Iglesia y de la presencia física del clero en el territorio nacional, sobre lo que ya han sido ofrecidos datos por los estudiosos de la historia social o económica de la iglesia $^{2}$, nos queda un interrogante por despejar: cuál era la religiosidad y la mentalidad del pueblo en la época de la caída del antiguo régimen.

Por lo que concierne a la confesionalidad del pueblo español a principios del siglo XIX, se han estudiado las circunstancias en que se redactó el artículo 12 de la Constitución de Cádiz que establecía que «la Religión de la Nación española es y será perpetuamente la católica, apostólica, romana, única verdadera». Tanto La Parra como Revuelta afirman que esta confesión religiosa del artículo 12 simplemente "otorgaba rango constitucional al hecho de la profesión católica del pueblo español» que entonces era una realidad «incuestionable» ${ }^{3}$. Aunque quizás hubo una minoría que aceptó este artículo movida por alguna intención política y no por la pág. 10.

Dufour, Gérard, Sermones revolucionarios del Trienio Liberal (1820-1823), Alicante, 1991,

2 Nos limitamos a dar algunos ejemplos. Domínguez Ortiz, Antonio, Sociedad y Estado en el siglo XVIII español, Barcelona, 1976, págs. 359-382., CALLAHAN, William J., Iglesia, poder y sociedad en España, 1750-1874, Madrid, 1989, págs. 15-35 y 45-53 y sobre Cataluña, FELIU । MONTFORT, Gaspar, La clerecia catalana durant el Trienni Liberal, Barcelona, 1972, págs. 9-16 y 19-22, BADA, Joan, L'església de Barcelona en la crisi de l'antic règim (1808-1833), Barcelona, 1984, págs. $115-166$.

3 La expresión es de Revuelta. ReVuelta GonzÁlez, Manuel, "Discrepancias de liberales y absolutistas en la configuración de la Iglesia», en M. Andrés et al., Aproximación a la historia social de la lglesia española contemporánea, Madrid (EI Escorial), 1978, pág. 13. Cf. LA PARRA LóPEZ, Emilio, El primer liberalismo y la Iglesia, Las Cortes de Cádiz, Alicante, 1985, capítulo II (El hecho religioso en las Cortes de Cádiz). Revuelta GonzÁlez, Manuel, "La confesionalidad del estado en España», en LA PARRA López, Emilio y Jesús Pradells (eds.), Iglesia, sociedad y estado en España, Francia e Italia (ss. XVIII al XX), Alicante, 1991 
sincera fe católica, las dudas sobre la unidad religiosa no llegaban todavía a las clases populares. El pueblo se mostraba reacio a la tolerancia religiosa ${ }^{4}$.

Ahora bien, debido a las alteraciones ocurridas en la vida española tras 1808 y a la experiencia del exilio sufrida por muchos liberales durante el sexenio, ¿había cambiado mucho la situación en 1820, cuando se estableció por segunda vez el régimen liberal? Hay que pensar primero hasta qué punto las dudas sobre la fe católica eran compartidas por los doceañistas y la nueva generación de los liberales del año veinte, y luego si, debido a la influencia de éstos, la religiosidad y mentalidad del pueblo habían sufrido algún cambio. Varias monografías de estos años han señalado la existencia de una corriente de pensamiento radical sobre la reforma de la Iglesia española, a la que podríamos llamar como «catolicismo liberal» o «liberalismo cristiano" ${ }^{5}$, sin embargo, al hablar de su influencia sobre las capas liberales o sobre el pueblo no podríamos traspasar el límite de las hipótesis por carencia de fuentes ${ }^{6}$. Otro punto que hay que tener en cuenta será la diferencia entre la situación de las ciudades grandes y la de los pueblos. Cuando hablamos de la unidad religiosa o de la devoción del pueblo español, tenemos en la mente la imagen de una aldea montañosa con su párroco, donde todo el mundo se conoce. Pero es posible que en las ciudades grandes como Barcelona, que además de tener

4 LA Parra, El primer liberalismo..., págs. 47 y ss.

5 Después de los valiosos estudios de Dufour como: Dufour, Gérard, Juan Antonio Llorente en France (1813-1822). Contribution à l'étude du libéralisme chrétien en France et en Espagne au début du XIX sièle, Ginebra, 1982.y «La Crónica religiosa: Un intento de liberalismo cristiano, ¿español o francés?» en GIL Novales, Alberto (ed.), La prensa en la revolución liberal: España, Portugal y América Latina, Madrid, 1983, han aparecido monografías que plantearon una reconsideración de la corriente reformadora de la Iglesia española, que son: LA PARRA LóPEz, Emilio, «Antonio Bernabéu: Un clérigo constitucional» en Trienio, 3, 1984, HIGUERUELA DEL PINO, Leandro, «El catolicismo liberal durante el Trienio constitucional», en Homenaje a los profesores José $M$. Jover Zamora y Vicente Palacio Atard, Vol.II, Madrid, 1990. Idem, «La política eclesiástica según Juan Antonio Llorente: ideas europeas, coyuntura española», Hispania Sacra, 46, 1994, y muchos otros artículos que se encuentran en Libéralisme Chrétien et Catholicisme Libéral en Espagne, France et ltalie dans la première moitié du XIXe siécle, Aix-en-Provence,1989. En este sentido una obra precursora fue: MARAVALL, Juan Antonio, «Sobre los orígenes y sentido del catolicismo liberal en España», en Homenaje a Aranguren, Madrid, 1972.

6 Cuando estudiamos la obra de Llorente, concluímos que «la imagen de las ideas religiosas de los liberales del Trienio Constitucional cambiaría totalmente según cómo estimáramos la influencia de las ideas de Llorente, en cuyas obras aparecen proposiciones tan radicales como la tolerancia religiosa, la secularización del matrimonio o la posibilidad del divorcio, prácticamente inexistentes en los escritos de los liberales españoles del mismo período", pero es difícil encontrar datos para estimar cuántas repercusiones e influencias ha tenido su obra. Cf. Yoshiko YamamiCHI «Discursos sobre una Constitución Religiosa de Juan Antonio Llorente y su censura por el obispado de Barcelona en 1820" (artículo en japonés), Estudios de Historia de España, núm. 11, Tokio, 1997. 
un mayor número de feligreses en cada parroquia ${ }^{7}$ acogía a inmigrantes de otros lugares ${ }^{8}$, la situación fuera completamente distinta ${ }^{9}$.

En todo caso, está claro que aún nos queda un vasto campo por investigar en torno a la religiosidad y mentalidad del pueblo durante la primera mitad del siglo XIX. Este pequeño trabajo es un intento de aproximarse a la cuestión mediante el estudio de las celebraciones festivas, que es uno de los aspectos de la vida ciudadana en los que la religión ejerció una influencia más importante.

\section{FUENTES PARA EL ESTUDIO DE LAS FIESTAS LIBERALES DEL TRIENIO CONSTITUCIONAL}

Son escasos los estudios existentes sobre las fiestas liberales en España ${ }^{10}$, en comparación con la abundancia bibliográfica de los estudios sobre las fiestas revolucionarias de la Revolución Francesa representada por las obras de Mona Ozouf o de Michel Vovelle. Sin embargo, no cabe duda de que los estudios sobre el liberalismo y la iglesia del mismo período como la obra de Revuelta ${ }^{11}$ y las obras ya citadas de Feliu y de Bada sobre Cataluña, son básicas para obtener una idea sobre la cuestión.En este sentido también han sido muy útiles algunos libros recientes sobre la historia del anticlericalismo español ${ }^{12}$. Para el estudio de las costumbres y

7 Dufour calcula como promedio de toda España unas 550 almas por parroquia, unas diez mil por parroquia en Madrid y unas mil en Segovia. Cf. Dufour, Sermones..., pág. 11.

8 Por ejemplo, el número de los napolitanos y sardos que se refugiaron en Barcelona después del fracaso de la insurrección en marzo de 1821 se estima como máximo en quinientos. Cf. BADA, L'església de Barcelona..., págs. 344-345.

9 Por ejemplo, Bada ve clara la señal de la progresiva descristianización en el descenso del cumplimiento pascual en Mataró y en Barcelona. En Mataró entre 1815 y 1817 el número de no cumplidores pasó de 3 a 37 y en Barcelona, en 1826, (no cumplidores) eran 316 matrimonios, 464 hombres y 412 mujeres, con un total de 1508 personas. Su distribución por parroquias era: St. Jaume (5 matrimonios, 19 hombres y 7 mujeres), Sta. Maria (19 mat. 30h. y 13m.), Pi (290 mat., 397h. y 391m.), St. Cugat (5h.y 1m.), St. Pere (2 mat. y 13h.), St. Miquel (ninguno). BADA, L'esglesia de Barcelona..., pág. 256. - Además de la cifra elevada de no cumplidores, es interesante la desigualdad de su distribución.

10 Sobre las fiestas liberales de España sólo se encuentran: Butrón Prida, Gonzalo, «La fiesta revolucionaria en el Cádiz Constitucional», en FERnÁndez AlbalAdejo, Pablo y Margarita Ortega López (eds.), Antiguo Régimen y liberalismo. Homenaje a Miguel Artola, Vol. 3. Política y Cultura, Madrid, 1995, GuERENA, Jean-Louis, «Fête nationale, fête populaire? Les premiéres commmémorations du 2 mai (1809-1814)", en AYMES, Jean-René y Javier Sebastián (eds.), La imagen de Francia en España (1808-1850), Bilbao, 1997.

11 Revuelta González, Manuel, Política religiosa de los liberales en el siglo XIX. Trienio constitucional, Madrid, 1973.

12 La PARRA LOPEZ, Emilio, y Manuel SuÁrez Cortina (eds.), El anticlericalismo español contempráneo, Madrid, 1998. Revuelta GonzÁlez, Manuel, El anticlericalismo español en sus documentos, Barcelona, 1999. 
fiestas, existen obras tan valiosas y completas como el Costumari Català de Joan Amades, y el Calaix de Sastre, famoso diario del Baró de Maldà lleno de informaciones muy útiles ${ }^{13}$.

Para el estudio de las fiestas liberales se cuenta con diversas fuentes documentales, desde la prensa hasta los manuscritos contemporáneos. La fuente principal de este trabajo ha sido el Diario manuscrito de un zapatero que se llama Mateu Crespi, que se puede consultar en el Arxiu Municipal de Barcelona 14. Lo hemos utilizado porque es un diario que pretende reflejar con objetividad la historia de la ciudad. Aun siendo conciso, proporciona a veces informaciones que no se podrían encontrar en los periódicos de la época. Nos parece que es una fuente adecuada para obtener una visión general de su tiempo. Como fuentes complementarias hemos utilizado otros manuscritos contemporáneos, la Breve relació del Fr. Joan Serrahima ${ }^{15}$ y el Fragmento del diario de un miliciano anónimo ${ }^{16}$. También hemos consultado otra fuente esencial: la Correspondencia del oficio del vicario general de la época Pedro Josef Avellá y Navarro ${ }^{17}$ y algunos sermones impresos del clero liberal y otros folletos relacionados con las

13 Amades, Joan, Costumari Català. El curs de lany, 5 vols., Barcelona, 1950-1956, y 19821983. BARÓ DE MALDÁ (Rafael d'Amat i de Cortada), Calaix de Sastre, edición a cargo de Ramón Boixareu, 9 vols., Barcelona, 1987-1999(?).- También hemos consultado otras obras como: AmADES, Joan, Auca dels costums de Barcelona, Barcelona, 1937. Idem, Auca de les funcions de Barcelona, Barcelona, s.d. Idem. Les diades populares catalanes, 4 vols., Barcelona, 1932-1949. ALmERIC, Lluís, Tradicions, festes $i$ costums populars de Barcelona, Barcelona, $1989\left(1 .^{a}\right.$ ed. en castellano, 1944), y los dos libros de Montserrat Rumbau escritos a partir del Calaix de Sastre: La Barcelona de fa 200 anys, Barcelona, 1990. Idem, La Barcelona de principis del segle XIX, Barcelona, 1995.

14 Crespl, Mateu, Diario de Memorias de Barcelona y hotras partes del Año 1820 hasta el Año 1849, Arxiu Municipal de Barcelona. El manuscrito lleva una nota biográfica sobre el autor escrita por su nieto Joan Salvat i Crespi a su donación en 1932. El autor es un liberal moderado e instruido, esto se nota entre otras cosas por su facilidad para escribir en castellano. Fue elegido Prohombre Tercero del gremio de zapateros en los años 1824 y 1825.- El manuscrito sobre los años del Trienio Constitucional suma unas 384 páginas en folio tamaño A5, sin incluir los índices.

15 Serrahima, Fr. Joan, Breve relació de lo que succehi en la proclamació de la Constitució dita per malicia espanyola..., Arxiu de la Corona d’Aragó, Monacales-Universidad, Vol. 27. Son unas memorias escritas en 1824 por un prelads -absolutista, por supuesto- de carmelitas de Barcelona que era prior desde septiembre de 1821.

16 Este manuscrito núm. 737 de la Biblioteca de Catalunya ha sido publicado por OLLÉ RoMEU transcrito con notas detalladas, Josep Maria: Anònim, Successos de Barcelona (1822-1835), Barcelona, 1981. Se trata del diario de un miliciano más radical y sencillo que Crespi y describe con gran viveza lo ocurrido en Barcelona. El estilo del diario es el del catalán hablado. Es una lástima que se haya perdido la parte anterior a noviembre de 1822.

17 Avellá y Navarro, Pedro Josef, Correspondencia del oficio (1812-1830), en 2 vols. Arxiu Diocesà de Barcelona. Son dos volúmenes muy gruesos,encuadernación de la copia manuscrita de toda la correspondencia oficial remitida por el obispado de Barcelona cuando Avellá estaba en el cargo de vicario general. En cuanto a la época del Trienio Constitucional, faltan datos desde el 3 de abril hasta el final del año 1821 (cuando Avellá estaba desterrado por una revuelta liberal), y de los años 1823 y 1824 cuando había dos autoridades eclesiásticas (una liberal en Barcelona y otra absolutista, de Avellá, en Manresa y otra parte del obispado), sólo se encuentran los documentos de su parte. 
fiestas ${ }^{18}$. No hemos tenido ocasión de consultar las fuentes del Ayuntamiento ni tiempo suficiente para estudiar toda la prensa de la época, este trabajo tendrá un carácter introductorio limitándonos a trazar con él unas líneas generales.

\section{TRES CLASES DE FIESTAS EN LA BARCELONA CONSTITUCIONAL}

Si observamos el calendario de las fiestas de Barcelona durante el Trienio Constitucional, fácilmente se advertirán algunas de sus características como, por ejemplo, la frecuencia de las fiestas en general. (Tanto el calendario como la cronología detallada de las fiestas - Apéndice 1- están elaborados básicamente según las descripciones del Diario de Mateu Crespi. Se han añadido unos símbolos para facilitar su análisis). Casi todas las fiestas y celebraciones, salvo la bendición de la bandera, se celebraron en los días laborales del calendario católico en que las iglesias no estaban ocupadas por las misas y, con tantas rogativas y novenarios (celebraciones con el símbolo $t$ en la «cronología»), es admirable su frecuencia. Eran, pues, muy frecuentes las ocasiones en que los vecinos de Barcelona podían sentir el ambiente religioso.

Luego, se advierte también la decadencia de las fiestas tradicionales, particularmente las del invierno - que eran más importantes en la sociedad del antiguo régimen-y la aparición de las nuevas fiestas principalmente en primavera o en verano. Además, quizás sea mera coincidencia pero la fecha de las principales fiestas liberales era cercana a la de las fiestas tradicionales. Es interesante comprobar que en estos casos parece que la fecha influye en las celebraciones. Por ejemplo, aparecen los gigantes del Corpus en el desfile del día del Rey Fernando (Cf. Tabla 1).

\footnotetext{
is Casamada, Fr. Manuel, Tributo de gratitud a las víctimas del Dos de Mayo de 1808, cuya sangre sentó la primera piedra del santuario de nuestra independencia, y cuyas cenizas levantaron las paredes del santuario de nuestra libertad. Elógio fúnebre, Barcelona, 1820. Idem, El Imperio de las leyes sostenido y afianzado por las víctimas del 7 de julio de 1822 en Madrid: elógio fúnebre, que en las solemnes ecsequias celebradas por el escelentísimo ayuntamiento constitucional de Barcelona, El día 29 de agosto de 1822,..., Barcelona, 1822., Jaumeandreu, Agustín, Sermón que el día 4 de abril de 1820 en la Iglesia parroquial de Sta. María del Mar de esta ciudad en la solemne función que en acción de gracias por la feliz publicación de la Constitución Política de la Monarquia Española..., Barcelona, 1820. JAUMEANDREU, Eudaldo, Elogio fúnebre que en las solemnes ecsequias celebradas por disposición de la Junta Patriótica de Barcelona dedicó a D. Luis Lacy, dijo en la parroquial iglesia de Santa María del Mar..., Barcelona, 1820. Idem, Oración inaugural que en la abertura de la Cátedra de Constitución..., Barcelona, 1820. Pujot, Alberto, Catecisme Politich al objecte de instruir als catalans en los drets, privilegis y ventajes quels proporciona la Constitució politica de la monarquía espanyola y las obligacions quels imposa, Barcelona, 1820. Idem, Las ventajas que resultan á la Nación Española de prohibir la Constitución el egercicio de cualquiera otra religión que no sea la católica, apostólica, romana...: Sermón del 10 de abril de 1821. Barcelona, 1821. Relaciones de la pompa fúnebre que Barcelona hizo al cadáver de D. Luis Lacy Capitán General de los Ejércitos nacionales..., Barcelona, 1820. UBARISco, Martillo, Lopecio y SELTA RUNEGA, La Libertad Restaurada, representación dramática patriótica, escrita para ejecutarse en el Teatro de Barcelona en el memorable día 2 de Mayo, Barcelona, 1820.
} 
Pero para un análisis más profundo hemos dividido las fiestas en tres clases: 1) Las fiestas tradicionales, 2) Las fiestas y celebraciones políticas o de conmemoraciones de los liberales, y 3) Las rogativas y otros ritos con causas inesperadas como la epidemia. Estudiaremos las características de cada una de estas tres clases de fiestas.

Calendario de las fiestas y celebraciones de Barcelona

\begin{tabular}{|c|c|c|c|}
\hline \multicolumn{2}{|c|}{$\begin{array}{c}\text { PRINCIPALES FIESTAS TRADICIONALES } \\
\text { DE BARCELONA } \\
\text { A PRINCIPIOS DEL SIGLO XIX }\end{array}$} & \multicolumn{2}{|c|}{$\begin{array}{l}\text { PRINCIPALES FIESTAS DE LA } \\
\text { BARCELONA CONSTITUCIONAL SEGÚN } \\
\text { EL DIARIO DE MATEU CRESPI }\end{array}$} \\
\hline \multicolumn{4}{|c|}{ INVIERNO } \\
\hline 21-diciembre & Santo Tomás & & \\
\hline 25-diciembre & Natividad del Señor & 25-diciembre & Navidad \\
\hline 26-diciembre & San Esteban & & \\
\hline 28-diciembre & Los Santos Inocentes & & \\
\hline 1-enero & Año Nuevo & & \\
\hline 2-febrero & Candelaria & & \\
\hline 12-febrero & Santa Eulalia & 12-febrero & Santa Eulalia \\
\hline Móvil & Carnaval & & \\
\hline Móvil & Miércoles de ceniza & Móvil & Miércoles de ceniza \\
\hline \multicolumn{4}{|c|}{ PRIMAVERA } \\
\hline Móvil & Semana Santa & $\begin{array}{l}\text { Móvil } \\
10 \text {-marzo }\end{array}$ & $\begin{array}{l}\text { Semana Santa } \\
\text { Proclamación de la Constitución } \\
\text { en Barcelona }{ }^{19}\end{array}$ \\
\hline 15-marzo & Santa Madrona & & \\
\hline 19-marzo & San José & 19-marzo & $\begin{array}{l}\text { Día de la Constitución (Fiesta } \\
\text { nacional) }\end{array}$ \\
\hline 23-abril & San Jorge & & \\
\hline \multirow[t]{2}{*}{ 29-abril } & San Pedro Mártir & & \\
\hline & & 2-mayo & $\begin{array}{l}\text { El Dos de Mayo (Fiesta } \\
\text { nacional) }\end{array}$ \\
\hline 3-mayo & Aparición de la Cruz & & \\
\hline 11-mayo & Sant Ponç & & \\
\hline Móvil & Ascensión del Señor & & \\
\hline \multicolumn{4}{|c|}{ VERANO } \\
\hline & & $\begin{array}{l}\text { 30-mayo } \\
\text { 31-mayo }\end{array}$ & $\begin{array}{l}\text { Día del Rey Fernando } \\
\text { Día de los muertos en defensa } \\
\text { de las libertades en España }\end{array}$ \\
\hline Móvil & El Corpus Christi & Móvil & El Corpus Christi \\
\hline 24-junio & San Juan & 24-junio & San Juan \\
\hline
\end{tabular}

\footnotetext{
19 El 10-marzo era fiesta nacional desde el año 1822 por ser el Día de la Matanza de Cádiz, pero no se celebró como tal.
} 
Calendario de las fiestas y celebraciones de Barcelona (continuación)

\begin{tabular}{|c|c|c|c|}
\hline \multicolumn{2}{|c|}{$\begin{array}{c}\text { PRINCIPALES FIESTAS TRADICIONALES } \\
\text { DE BARCELONA } \\
\text { A PRINCIPIOS DEL SIGLO XIX }\end{array}$} & \multicolumn{2}{|c|}{$\begin{array}{l}\text { PRINCIPALES FIESTAS DE LA } \\
\text { BARCELONA CONSTITUCIONAL SEGÚN } \\
\text { EL DIARIO DE MATEU CRESPI }\end{array}$} \\
\hline $\begin{array}{l}29 \text {-junio } \\
4 \text {-agosto } \\
\text { mediados } \\
\text { agosto }\end{array}$ & $\begin{array}{l}\text { San Pedro } \\
\text { Santo Domingo } \\
\text { Fiestas mayores en } \\
\text { los pueblos }\end{array}$ & 29-junio & San Pedro \\
\hline \multicolumn{4}{|c|}{ OTOÑO } \\
\hline $\begin{array}{l}\text { 24-septiembre } \\
\text { 1-noviembre } \\
\text { 2-noviembre } \\
\text { 11-noviembre }\end{array}$ & $\begin{array}{l}\text { Nuestra Señora de las } \\
\text { Mercedes } \\
\text { Todos los Santos } \\
\text { Todos los difuntos } \\
\text { San Martín }\end{array}$ & 24-septiembre & $\begin{array}{l}\text { Apertura de las Cortes de } \\
\text { Cádiz }\end{array}$ \\
\hline
\end{tabular}

\subsection{Decadencia de las fiestas tradicionales}

Está clara la decadencia de las fiestas tradicionales. Por ejemplo, con la única excepción del Copus Christi, que era la fiesta más importante y tradicional, no se efectuaron las procesiones generales en ninguna otra ocasión. Muchas veces encontramos expresiones tales como "con motivo de suspenderse la procesión acostumbrada en los años anteriores, se hará la función siguiente...». En estos casos había misa en algunas iglesias, se cantaban canciones sagradas y pronunciaba el sermón algún clérigo liberal ${ }^{20}$. Se puede decir que tanto la autoridad civil liberal como la eclesiástica, cuyos miembros eran ciertamente absolutistas, heredaron la mentalidad ilustrada de controlar las fiestas y de rechazar la superstición barroca. La prohibición de reunirse después de la puesta del sol aún siendo en la misa o para una procesión ${ }^{21}$, la prohibición de los fuegos artifi-

20 Por ejemplo, para el Domingo de Ramos de 1820 se lee, "Hoy domingo de Ramos, con motivo de suspenderse la Procesion acostumbrada en los años anteriores, se hará la funcion siguiente: á las cuatro y media de la tarde, en la capilla de nuestra Señora de los Dolores, del Orden de PP. Servitas de esta ciudad, se cantará la corona de la Santísima Virgen, con asistencia de la música de la santa iglesia Catedral, y sermon que predicará el R.P.Fr. Jaime Pujol, de dicha Orden; concluyéndose la funcion con el devoto himno Stabat que cantará la muy Rda. Comunidad. Hoy domingo de Ramos, en la parroquial iglesia de San Jaime, por la tarde á las cuatro y media rezará el santísimo rosario, y á espensas de algunos devotos de nuestra Señora de los Dolores cantará la música de la santa iglesia Catedral un solemne Stabat Mater: seguirá despues el sermon que hará el R.P.Fr. Gaspar Casanova, predicador general de San Francisco de Asís; y finalizará dicha música con la Salve." Diario de Barcelona, 26-marzo-1820, pág. 694.

21 Prohibición de las misas de noche de la Navidad: «Aunque no hay cosa mas justa que emplear en el canto de las divinas alabansas la noche en que renovamos cada año la memoria del Nacimien- 
ciales y de los petardos en las verbenas de San Juan y San Pedro ${ }^{22}$, y la prohibición de las máscaras o disfraces durante el Carnaval ${ }^{23}$, son los ejemplos típicos. La autoridad municipal, mientras admitía unas nuevas diversiones como el teatro o los bailes de máscaras ${ }^{24}$, se mostraba muy inquieta por controlar la vida ciudadana ${ }^{25}$. Y la Iglesia, por su parte, procuraba ilustrar el culto del pueblo, porque todavía no se le había ocurrido la idea de reconocer y promover la religión "popular» para preservar al pueblo español de su descristianización ${ }^{26}$.

to de nuestro Salvador, dicta la prudencia y el verdadero zelo por Nuestra Santa Religion alterar esta antiquisima y venerable costumbre paraque no se repitan este año algunos excesos observados en los anteriores, y por lo mismo á tenor a lo dispuesto por el Ylmo. Sor. Obispo cuydará V. de que los maytines de Navidad se canten en esa Yglesia por la tarde debiendo quedar conducidos al dar las primeras oraciones, y que la misma llamada del gallo se cante a las cinco de la mañana y la de aurora a las seis, lo que comunico a V. para su inteligencia y puntual cumplimiento." Circular a todas las Yglesias de la Ciudad, 22-dic.-1820, Avellá, Correspondencia del oficio, Vol. I, pág. 353, doc. 919.Otro oficio del vicario general sobre la suspensión de la procesión de la Semana Santa: «...con tal que se retiren antes de obscurecer del todo como V.E. me indica no haré oposicion formal á que se hagan las procesiones..., pero con todo aunque no se use la misma indulgencia jusgo que tampoco se conseguirá que retiren antes de las 9 ó las 10 de la noche, y á fin de precaver todo exceso sin duda seria lo mas prudente suspenderlas por este año." Al Gefe Político, 17-marzo-1821, ibid., Vol. I, págs. 364365, doc. 981 .- (En las citas de los textos contemporáneos, conservamos la ortografía original, porque ésta ayudará a comprender el carácter de cada documento.)

22 De orden de los Alcaldes Constitucionales, "se manda que ninguna persona sea de la clasa sea pueda disperar ningun fusillaso ni cosa que sea de fuego artifixial y que nadia en la viguilia de San Juan y San Pedro puede encender fuegos por las callas y plazas bajo pena de 100 rs." Diario de Mateu Crespi, 22-junio-1820.

${ }_{23}$ Por el orden de los Alcaldas se manda: «...que persona alguna se presentare en las plazas y callas con mascara ó traje deshonesto en los tres dias de carnabal el que contraviniera á esta orden sera castigado con todo el rigor de la Ley.»El mismo día también se manda «que los muchachos ni persona alguna anden tirando piedras por ninguna parte bajo pena de 8 pesetas..." idem., 16-feb.-1822.

24 El gobierno municipal permitió los bailes de máscaras en la temporada de Carnaval y para unos días especiales, con la condición de destinar todos sus ingresos a la beneficencia. CAPMANY, Aurelio, Un siglo de baile en Barcelona. Qué y dónde bailaban los barceloneses el siglo XIX, Barcelona, 1947, págs. 12-13. En el «Apéndice C» de dicha obra se lee el reglamento detallado del ayuntamiento sobre los bailes públicos, 30-dic.-1820.- La única diferencia entre el régimen liberal y el absolutista era que el primero permitía la entrada de las mujeres al teatro y otras funciones públicas. En el año 1824 cuando se volvió a abrir el teatro, se prohibió que los hombres y las mujeres estuvieran juntos como antes del año 1820. Diario de Mateu Crespi, 18-abril-1824.

25 Además de las ordenanzas sobre las fiestas, encontramos otras de la misma índole, cuyos motivos eran el control de los vecinos, o la limpieza de las calles. Un ejemplo de esta última: «que todos los vecinos sin excepcion tengan bien limpias las callas cuada cual la parte que le toque barrandolos todes los Miercoles y Sabados y regandola desde hoy asta ultimo de Setiembre dos veses al dia. $Y$ proiben que de dia ni de noche se puede echar aguas sucias cortezas de melon desperdicios de verduras ni frutas...» idem., 21-junio-1821.

${ }_{26}$ Callahan señala que en el régimen moderado que comenzó en 1844, la iglesia comprendió que las creencias primitivas tenían profundas raíces de las que podía sacar partido. Así la religión «popular» se introdujo de lleno en la vida de la Iglesia. Por ejemplo, entre los eclesiásticos se dio crédito a historias extraordinarias sobre sucesos milagrosos que antes hubieran dado lugar a investigaciones inquisitoriales. Cf. CALLAHAN, Iglesia, poder y sociedad..., págs. 226 y ss. 
Aunque Dufour señala que el sermón se había transformado verdaderamente en una representación pública y que habían aparecido algunos oradores muy populares ${ }^{27}$, nosotros dudamos que los sermones del clero liberal atrajeran tanto el interés del pueblo como las procesiones de teatralidad barroca. Quizás la frecuencia de rogativas y novenarios, que estudiaremos después, reflejaban el ansia del pueblo por continuar con la devoción tradicional.

\subsection{Creación de las fiestas liberales}

La decadencia de las fiestas tradicionales no significó una reducción del número de fiestas en general. La autoridad liberal organizó fiestas de carácter político o conmemoraciones como el aniversario de la proclamación de la Constitución, el aniversario de la muerte del general Lacy ${ }^{28}$, el Dos de Mayo y el día del Rey Fernando. Por su parte algunas asociaciones como el batallón de la Milicia o la Sociedad Patriótica realizaban sus propias celebraciones (cf.celebraciones con los símbolos $\rho$ y de la "cronología»). Después del verano de 1822, cuando Cataluña entró en plena guerra con los absolutistas, muchos milicianos y soldados liberales resultaron muertos. Se decía que algunos de sus funerales eran tan solemnes y con tanta concurrencia como si hubieran sido los funerales de un general famoso ${ }^{29}$. (Se ha puesto el símbolo $\nabla$ a ese tipo de funerales.)

27 Dufour, Sermones..., págs. 12-13.

28 Para los barceloneses del Trienio Constitucional no existía otro héroe mayor ni más popular que el general Lacy. El general Lacy fue fusilado el 5 de julio de 1817 en los fosos del Castillo de Bellver, en la isla de Mallorca, por encabezar el pronunciamiento que a principios de abril había fracasado en Barcelona. Era héroe en un doble sentido: salvador de la patria en Cataluña durante la guerra contra Napoleón en 1811 y víctima del absolutismo en 1817. Sobre su pronunciamiento de 1817, cf. FonTANA, Josep, La quiebra de la monarquía absoluta 1814-1820, Barcelona, 1974, págs. 245-256.- Su funeral tuvo lugar los días cinco y seis de julio de 1820 . Más adelante hablaremos sobre esta ceremonia que fue una de los acontecimientos principales de la Barcelona Constitucional.

29 El funeral de un miliciano de Gracia, Francesc Sabartés ( Sabater» según Diario de Mateu Crespi) es un ejemplo representativo. Por la mañana el cura párroco, el Ayuntamiento y los milicianos trasladaron su cadáver desde Gracia hasta la puerta del Ángel donde se reunieron las autoridades y muchos de sus compañeros de armas portando hachas. Después del oficio de difuntos en la iglesia de la Mercé, la salida por la puerta de Ángel fue del tenor siguiente: «3 batidores del Escuadron de Artillaria y 2 Ayudantes de Plaza á caballo rompieron la marcha, seguia un infinidad de Milicianos de todos los Batallones y Oficiales de la guarnicion de la Plaza todos con achas..." seguian al ataúd sobre el que se habían depositado el sable y el fusil y una corona de laurel «llevadas por el Sr. Mayor de la plaza, un Sindico del Ayuntamiento y un Miliciano de la 3a. compañia del 3o. Batallon...», atrás siguen el Ayuntamiento de Barcelona y de Gracia, y miembros de otras autoridades civiles, militares y las milicias. Diario de Mateu Crespi, 17-dic.-1822. También en Anònim, Successos..., pág. 31. 
Por otra parte, la autoridad municipal intentaba secularizar el entorno público. Mandó retirar las imágenes de la Virgen y otras estatuas sagradas de las calles y plazas ${ }^{30}$. Con motivo de estos traslados se organizaron procesiones (celebraciones con el símbolo $\mathbf{Y}$ ).

Un acto similar pero con significado e importancia completamente distintos fue el traslado de la imagen de la Virgen de Montserrat a la ciudad de Barcelona el 6 de enero de 1823. La autoridad liberal no podía admitir la caída de la «Moreneta» en manos de los absolutistas porque, además de ser objeto de una amplia devoción popular, el color negro de la Virgen era también el color de los liberales en aquella época. Al mismo tiempo su traslado estaba motivado por la necesidad de mostrar la «religiosidad» de los liberales, para contrarrestar así la campaña de sus enemigos según la cual "los liberales eran destructores de la Religión" "31.

Ahora intentaremos analizar las fiestas liberales (con los símbolos $\odot \bigcirc$ en la «cronología») teniendo en cuenta los tipos de celebraciones, su simbología y los lugares en que se efectuaban.

\section{- Tipos de celebraciones en las fiestas liberales}

Primero veremos qué tipo de celebraciones se llevaron a cabo durante las fiestas liberales de Barcelona. Presentamos una tabla de estas celebraciones elaborada siguiendo el Diario de Mateu Crespi y otras fuentes complementarias (se ha puesto una $x$ en cada una de las ceremonias registradas). Un ejemplo de la tabla: durante la Publicación del juramento del Rey, del 13 al 15 de julio de 1820 , como ceremonia religiosa se cantó el Te-Deum en la Catedral con la asistencia de las autoridades civiles y militares, posteriormente se llevaron a cabo las ceremonias de carácter secular como descargas de salvas, formación y desfile con música del ejército y de las milicias y se dieron vivas. Durante tres noches seguidas se iluminaron las calles ${ }^{32}$.

30 Un ejemplo de tales ordenanzas: «Se mande á todos los vecinos que tengan ymagenes á los balcones ó á su lado y las colocadas en varias callas y plazas de la Ciudad que dentro el termino de 8 dias deben sacarlas ó tapizarlas y del contrario las mandaran sacar y llevar á las iglesias mas inmediatas.» Diario de Mateu Crespi, 18-feb.-1823.

31 Diario de Barcelona, 7-enero-1823.

32 Diario de Mateu Crespi, 13-15 de julio de 1820. 


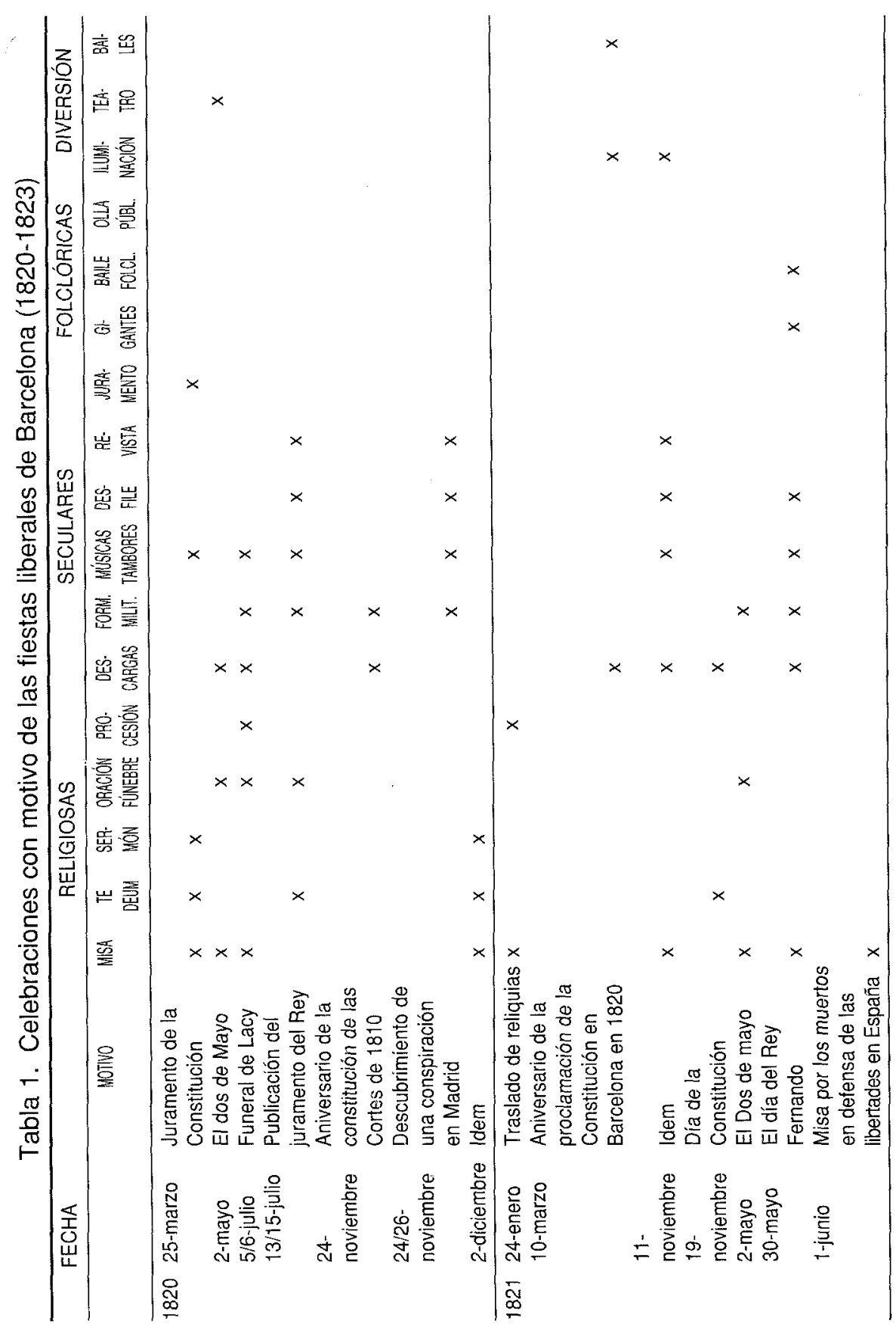




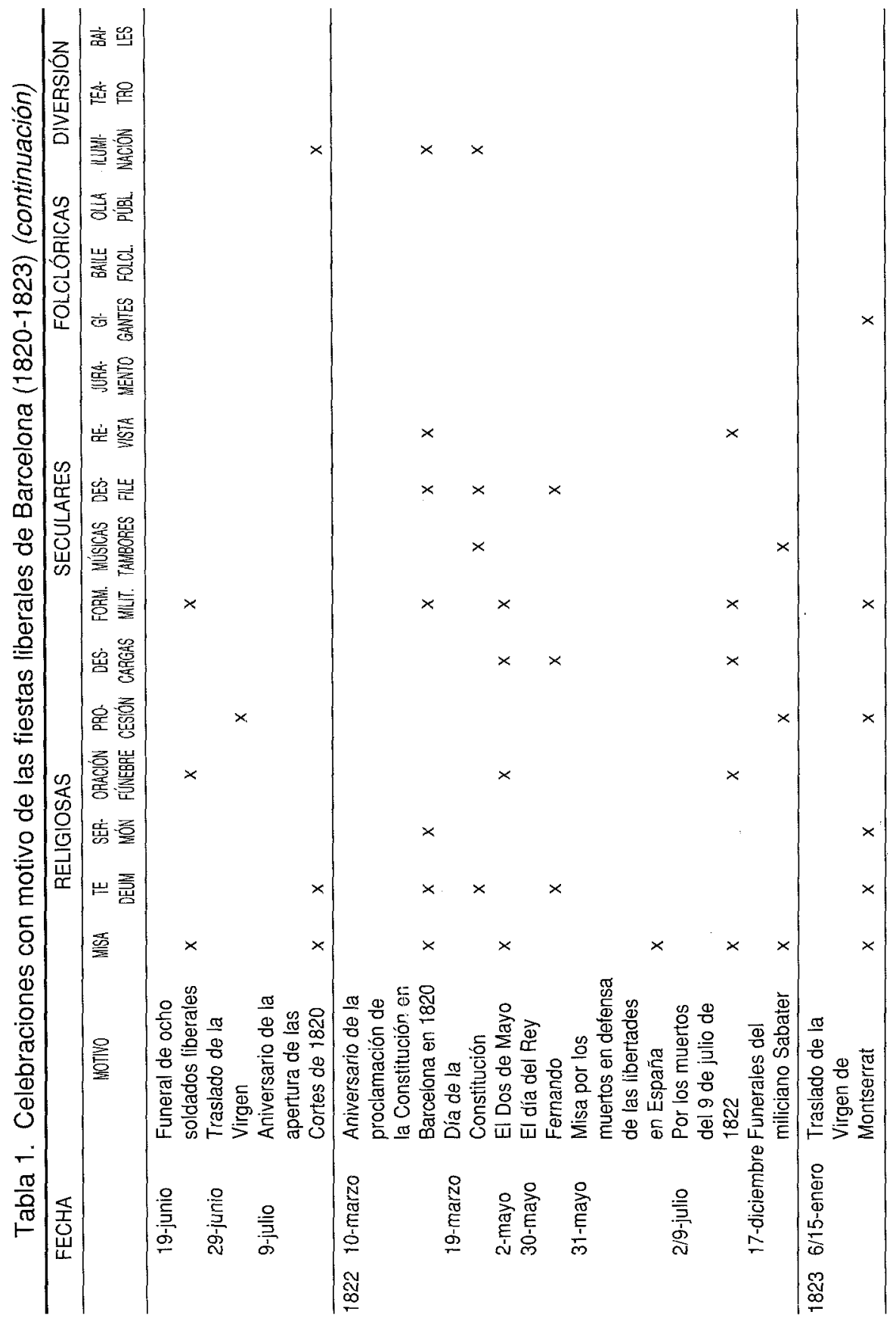




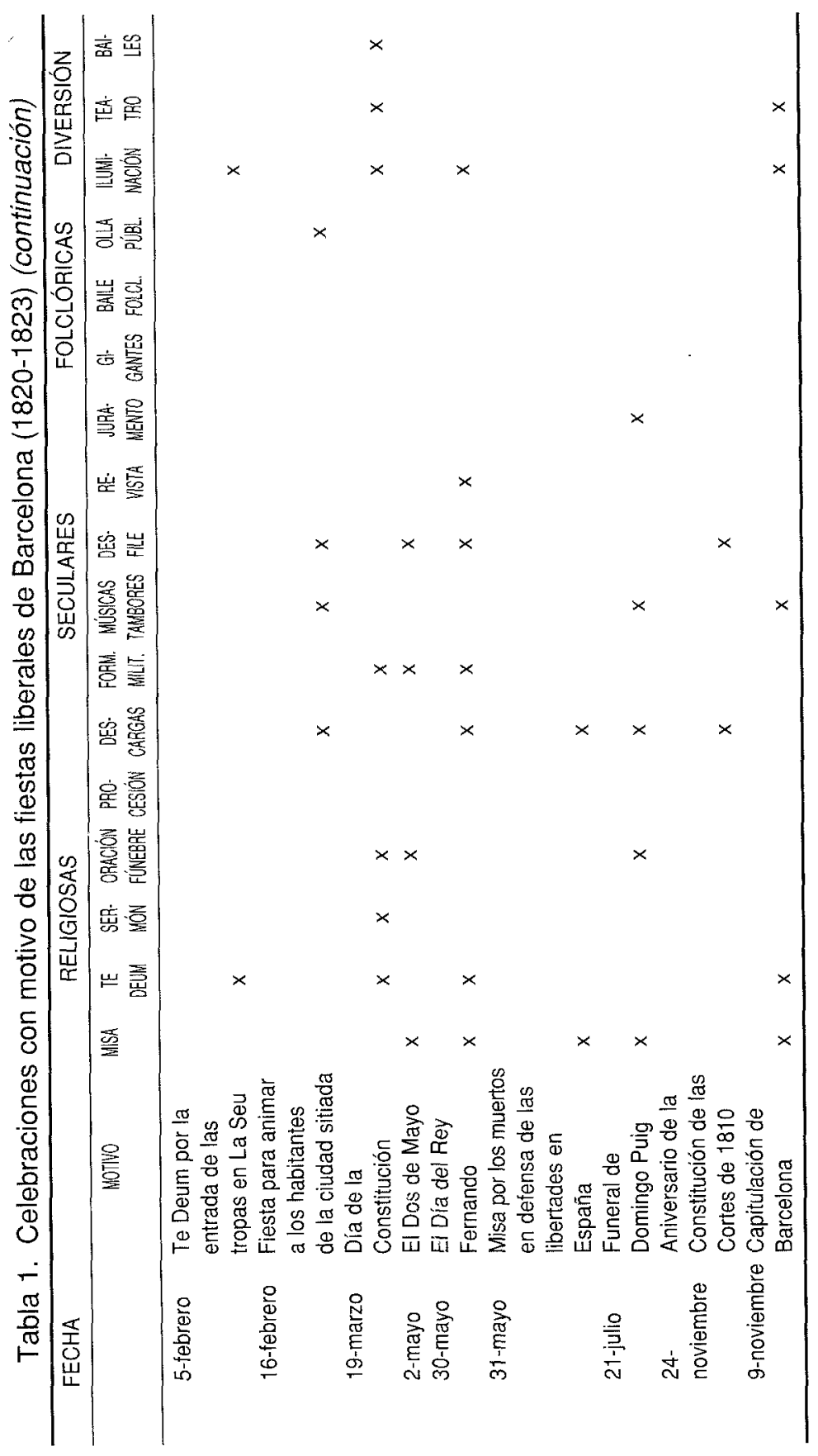


Para que una fiesta pudiera considerarse de gran pompa era necesario que combinara algunas ceremonias religiosas con ceremonias seculares y diversiones nuevas. En ocasiones, casi inadvertidamente, se añadían actuaciones folklóricas. Así, una gran celebración consistía generalmente en una misa o Te-Deum hacia las diez de la mañana en la Catedral, ceremonias seculares por la tarde en la Plaza de la Constitución o en las Ramblas, iluminación de las calles y teatro o baile de máscaras por la noche. La tendencia a iluminar las calles en las noches de fiesta posiblemente se justificaba, además de por su valor decorativo, por la razón práctica de hacerlas más seguras ${ }^{33}$. Es de destacar que aunque el motivo de la fiesta fuera puramente político en su celebración muchas veces no podía prescindirse del ritual religioso. Se podría decir que el Juramento civil, por ejemplo, no podía tomar el lugar de una ceremonia religiosa y que el liberalismo español no tenía ni pretendía otro culto civil, semejante al Culto a la Razón en los últimos momentos de la Revolución Francesa, que no fuera el católico. En dos ocasiones se alzó el Templo de la Libertad. La primera dentro de la Iglesia de Santa María del Mar durante el funeral del general Lacy los días 5 y 6 de julio de 1820. La segunda, el día de la Constitución del 19 de marzo de 1823, al aire libre, en la Plaza de la Constitución. No parece, sin embargo, que esto llegara a consagrar la libertad como un valor de culto.

Butrón Prida ilustra las fiestas liberales del Cádiz del mismo período poniendo énfasis en aspectos como la consagración de nuevos valores y la sensibilidad romántica ${ }^{34}$. Sin embargo, por lo menos en Barcelona, esos aspectos nuevos siempre estaban acompañados de otros que no eran tan nuevos, por ejemplo, el Te-Deum, las procesiones o los desfiles de gigantes. Entre esos aspectos «antiguos" hay que distinguir las ceremonias de la religión católica oficial de los actos tradicionales folklóricos. Porque el Te-Deum y otras ceremonias religiosas simbolizan el carácter del liberalismo español que establecía la confesionalidad del Estado, cuyo catolicismo era el de los ilustrados, mientras que los desfiles de gigantes y otros actos folklóricos que creemos que surgieron sin ninguna intención clara, pertenecían a los recuerdos del pasado popular, a los que se daría nueva vida en la segunda mitad del siglo.

33 Fray Serrahima, criticando su costo elevado, dijo sobre una fiesta para celebrar la apertura de las Cortes de primero de julio de 1820 que «era menester toda la paciencia de un Job pera assistir a semblans funcions, que se deian Patrioticas... En la nit hague illuminacio general, y lo gasto que se feu pera illuminar la rambla, y muralla de Mar fou excesiu, „SERRAHIMA, Breve relació..., pág. 236.

34 Butrón Prida, op. cit. 
Sin embargo, compartimos la opinión de Butrón de que las decoraciones de los monumentos efímeros y el contenido de los discursos o las oraciones fúnebres estaban compuestas con la nueva sensibilidad y gusto del romanticismo. Un ejemplo representativo fue el Templo de la Libertad alzado con ocasión del funeral del general Lacy. Según la descripción del folleto redactado por la Junta Preparatoria del funeral ${ }^{35}$, era un templo de ocho columnas de estilo corintio que imitaban el mármol del país y cuya decoración simulaba el bronce antiguo. Numerosas imágenes alegóricas simbolizaban los triunfos obtenidos por el ejército. También figuraban los héroes muertos en defensa de las libertades: Padilla y Lanuza, de la revuelta de los Comuneros del siglo XVI ${ }^{36}$, y Porlier, Mina, Sánchez Barbero, Vidal, Tirado y Acevedo del siglo XIX. Las columnas sostenían una cúpula y sobre ésta una estatua representaba la religión católica «cubriendo con su augusto manto los atributos de la monarquía española constitucional, y dispensando una corona al héroe" ${ }^{37}$. No transcribiremos todos los detalles de la decoración, pues ocupa ocho páginas en la obra citada. Sin embargo, merecen atención el gusto extraordinario por simbolizar los hechos históricos mediante estatuas o cuadros alegóricos y el elevado interés en los héroes y mártires patrióticos.

A continuación escogeremos algunas fiestas principales y nos centraremos en el estudio de los símbolos que en ellas se utilizaban.

\section{- Símbolos nuevos y símbolos tradicionales}

Examinemos de nuevo el funeral del general Lacy. Fue organizado por los dirigentes liberales que establecieron el régimen liberal en Barcelona y que solían reunirse en algún café o en la Sociedad Patriótica ${ }^{38}$. La publi-

35 Relaciones de la pompa fúnebre que Barcelona hizo al cadáver de D. Luis Lacy Capitán General de los Ejércitos nacionales..., Barcelona, 1820.

36 Butrón señala la celebración de una fiesta con motivo del aniversario de la muerte de los líderes comuneros el abril de 1822 en Cádiz y la publicación de un decreto de las Cortes de 14 de abril del mismo año, que declarába Beneméritos de la Patria a Juan de Padilla, Juan de Lanuza y demás defensores principales de las libertades de Castilla y Aragón, y afirma que «ambos condicionantes, la comunería y el romanticismo, pudieron llevar a la confluencia de la iniciativa oficial con la privada». Butrón Prida, op. cit., pág. 444.

37 Relaciones..., pág. 24.

38 La junta preparatoria se organizó el 17 de marzo, una semana después de la proclamación de la Constitución en Barcelona (ibid., pág. 7). Se puede pensar que los que prepararon el funeral de Lacy pertenecían al mismo círculo de gente que los que prepararon la proclamación de la Constitución en dicha ciudad. Sobre los que prepararon la proclamación de la Constitución en Barcelona, Serrahima describe sus conspiraciones y reuniones secretas. SERRAMIMA, Breve relació..., pág. 233. 
cación redactada por la Junta Preparatoria está llena de alabanzas al mártir. Se le califica de "un segundo Padilla", con expresiones y términos de gusto propiamente romántico. Cuando se habla de la «nación» no hay duda de que con este término se referían a España y que los hechos históricos evocados no eran de la historia de Cataluña sino de la de toda España o de la Península Ibérica. Lo que queda claro es que consideraban a Lacy como a un héroe que había querido liberar "Cataluña», y que «la heroica Cataluña» tenía que honrar con justicia su memoria. En este sentido, si hubieran estado escritas en catalán, algunas expresiones parecerían las de un escrito del catalanismo finisecular ${ }^{39}$.

Era natural que en los funerales por los muertos en defensa de las libertades aparecieran conceptos como «el honor», «lo heroico», «la patria», "la libertad» y símbolos como la "corona de laurel». La misma solemnidad del acto manifestaba la alabanza a los héroes propia del sentimiento romántico. Resulta interesante observar qué personajes y qué hechos históricos eran elegidos y ensalzados. En este sentido, merecería la pena comparar determinadas celebraciones, sin embargo su extensión exige un nuevo trabajo enfocado desde el punto de vista de la memoria histórica o de la memoria colectiva.

Veamos cuáles eran los símbolos representativos de fiestas liberales como el aniversario de la proclamación de la Constitución en Barcelona o el Día de la Constitución. Los gritos que se daban eran parecidos: «Viva la Religión, la Nación y el Rey Constitucional» ${ }^{40}$, «Viva la Religión, la Constitución y el Rey Constitucional» "1, "Viva la Constitución, el Rey y la Patria» ${ }^{42}$. Igual que en el caso de las ceremonias, se produjo una combinación de símbolos nuevos de carácter político - como la «Constitución», el «Rey Constitucional» o la «libertad»- con otros símbolos que eran religiosos (cf. Cuadro: Símbolos...). Si consideramos que «Religión» significaba "culto católico establecido y protegido por la Constitución», se podría decir que ésta fue convertida también en un símbolo nuevo de carácter político.

Como puede verse en el cuadro adjunto, en el último año del Trienio Constitucional se llevaron a cabo dos celebraciones de diferente valor simbólico: el traslado de la Virgen de Montserrat, ya mencionado, y otra fies-

39 Por ejemplo: «víctima de honor y patriotismo, porque quiso hacer libre á Cataluña» o "¿Quién podrá dudar que la heroica Cataluña, conquistadora de Atenas, no tribute como en aquel emporio de las luces, el debido homenage á las virtudes de sus héroes?» Relaciones..., pág. 6.

40 Con ocasión de la publicación del juramento de la Constitución por el Rey (13 de julio de 1820). Diario de Mateu Crespi, de la misma fecha.

41 En el aniversario de la proclamación de la Constitución, ibid., 11 de marzo de 1821.

42 En el día del Rey Fernando. Ibid., 30 de mayo de 1821. 
Cuadro: Símbolos utilizados en las fiestas liberales

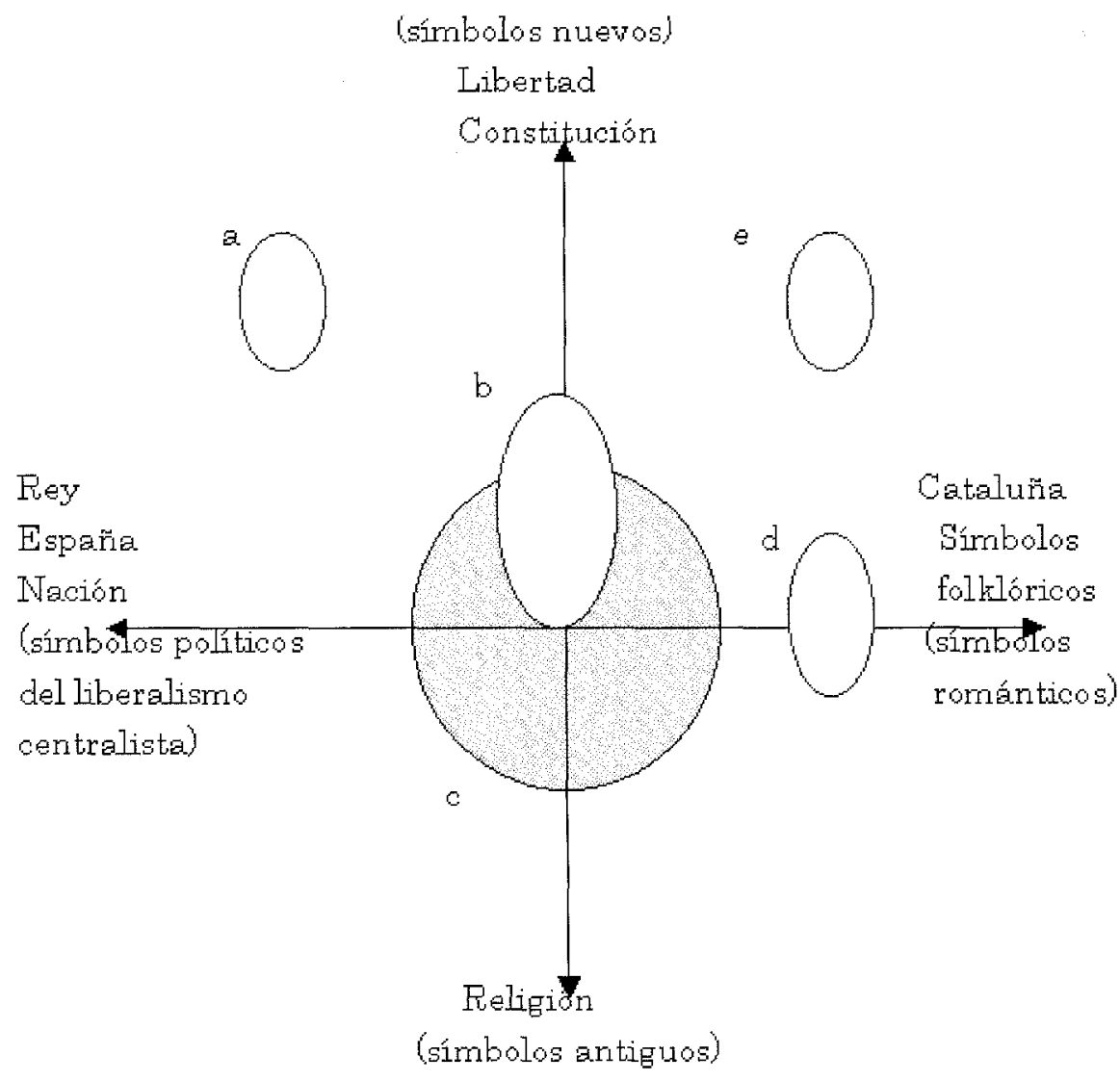

a: El Dos de Mayo.

b: El Funeral de Lacy (5-6-julio-i820).

c: Aniversario de la proclamación de la Constitución en Barcelona (10-marzo-1821) y otras fiestas principales.

d: El traslado de la Virgen de Montserrat (6-15-enero-1823).

e: Fiesta para animar a la ciudad sitiada (16-febrero-1823). 
ta para levantar los ánimos de la Barcelona sitiada celebrada el 16 de febrero de 1823. No aparecieron símbolos del Rey, ni de la Nación ni de España en ninguna de estas dos celebraciones. Parece que se identificaban más con la Barcelona o la Cataluña «liberal» y se había acentuado su solidaridad con las tierras en manos del ejército liberal. Este carácter fue debido en parte a la realidad de la guerra civil y al sitio que sufrió la ciudad y en parte al cambio de los miembros del ayuntamiento, que había caído en poder de los radicales. No es necesario repetir lo que significaba la Virgen de Montserrat, que era a la vez el símbolo de la religión popular y de la fe católica de los liberales.

La fiesta para animar a los habitantes de Barcelona (16 de febrero de 1823) fue una gran fiesta laica organizada con la intención de levantar los ánimos a los habitantes sitiados en la ciudad. Es curioso que en esta fiesta se enfatizara el espíritu de «igualdad» o de solidaridad entre todos los ciudadanos. Esto se muestra en dos aspectos completamente diferentes: en la participación activa de las mujeres y en los actos de caridad tradicional hacia los pobres. La celebración comenzó con el traslado de los cañones desde Atarazanas al fuerte de Canaletas - dos por los milicianos y los otros por las milicianas según el Fragmento del diario de un miliciano anónimo-, acompañados por el Jefe Político, el Ayuntamiento y la música del batallón de Jóvenes de la Milicia. Las «Señoras Milicianas» ${ }^{43}$ tiraban de los cañones. Después de un discurso del Alcalde Primero y de que toda la concurrencia gritara «viva la Constitución», pasaron a la Rambla donde se había preparado una olla pública de lujo para mil doscientos o mil quinientos pobres - «escodella, car de olla y un estofat y formatxe y pa y bi» según el miliciano anónimo- que fue servida por los miembros de la Autoridad y otros señores distinguidos. El miliciano anónimo comenta que este acto fue muy elogiado en la ciudad sitiada ${ }^{44}$.

\section{- Lugares donde se celebraban las fiestas}

Igual que para las celebraciones, hemos confeccionado una tabla en la que se indican con una $x$ los lugares donde se celebraban las fiestas liberales.

43 Ibid., 16 de febrero de 1823. y Anónim, Successos..., págs. 34-35.- Sobre la participación de las mujeres en las defensas del sistema liberal, que cristalizó en la formación de un batallón de milicianas presidido por la viuda del general Lacy, Olté Romeu señala en la nota de dicha obra. ibid., nota 24)-2.

$44 \quad \mathrm{lbid}$, pág. 35. Este comentario sería muy sincero, porque el mismo autor confiesa en el 30 de mayo de 1823, el día del Rey Fernando, que hubo una parada pero todos «anàrem mol descontens». Ibid., pág. 39. 


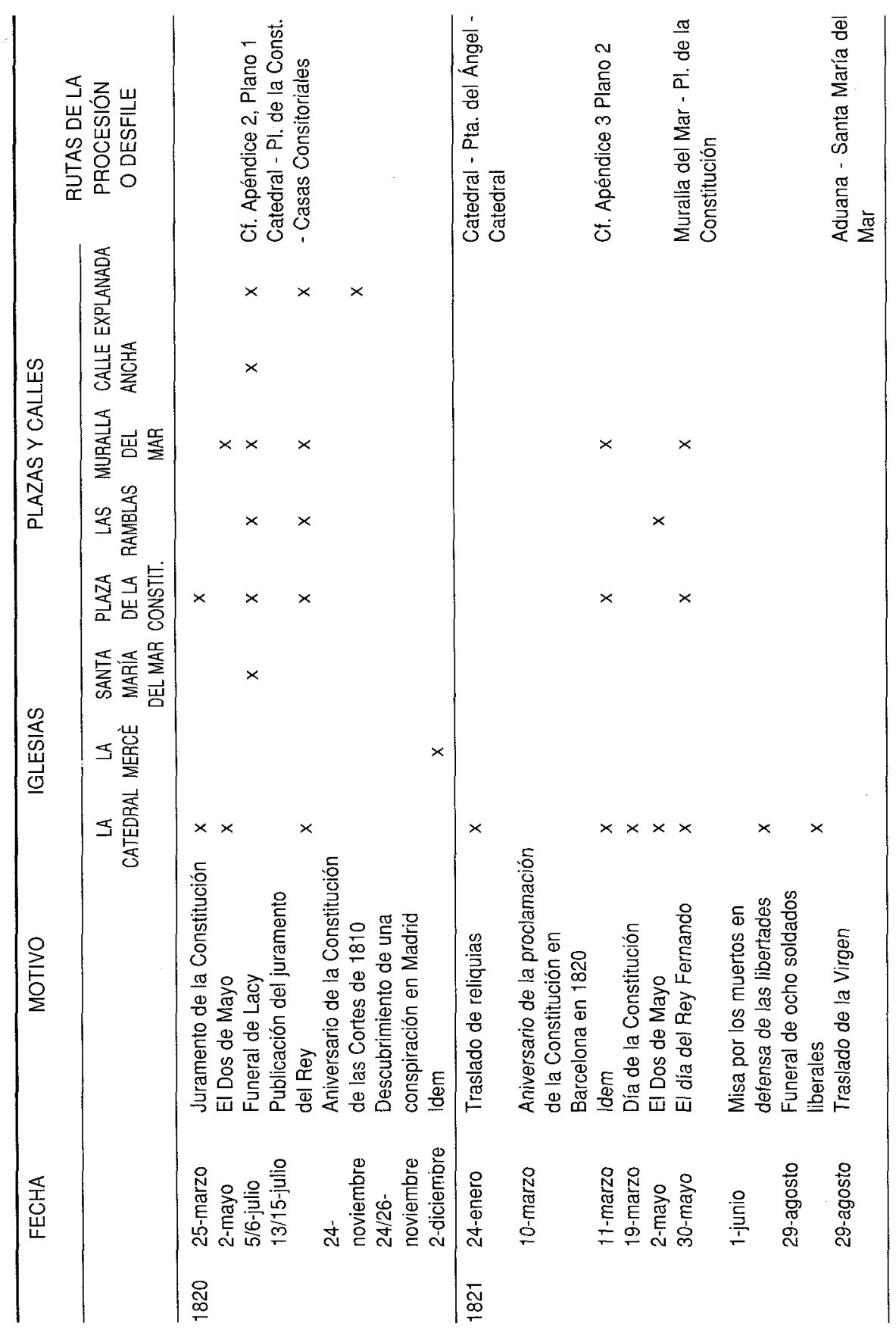




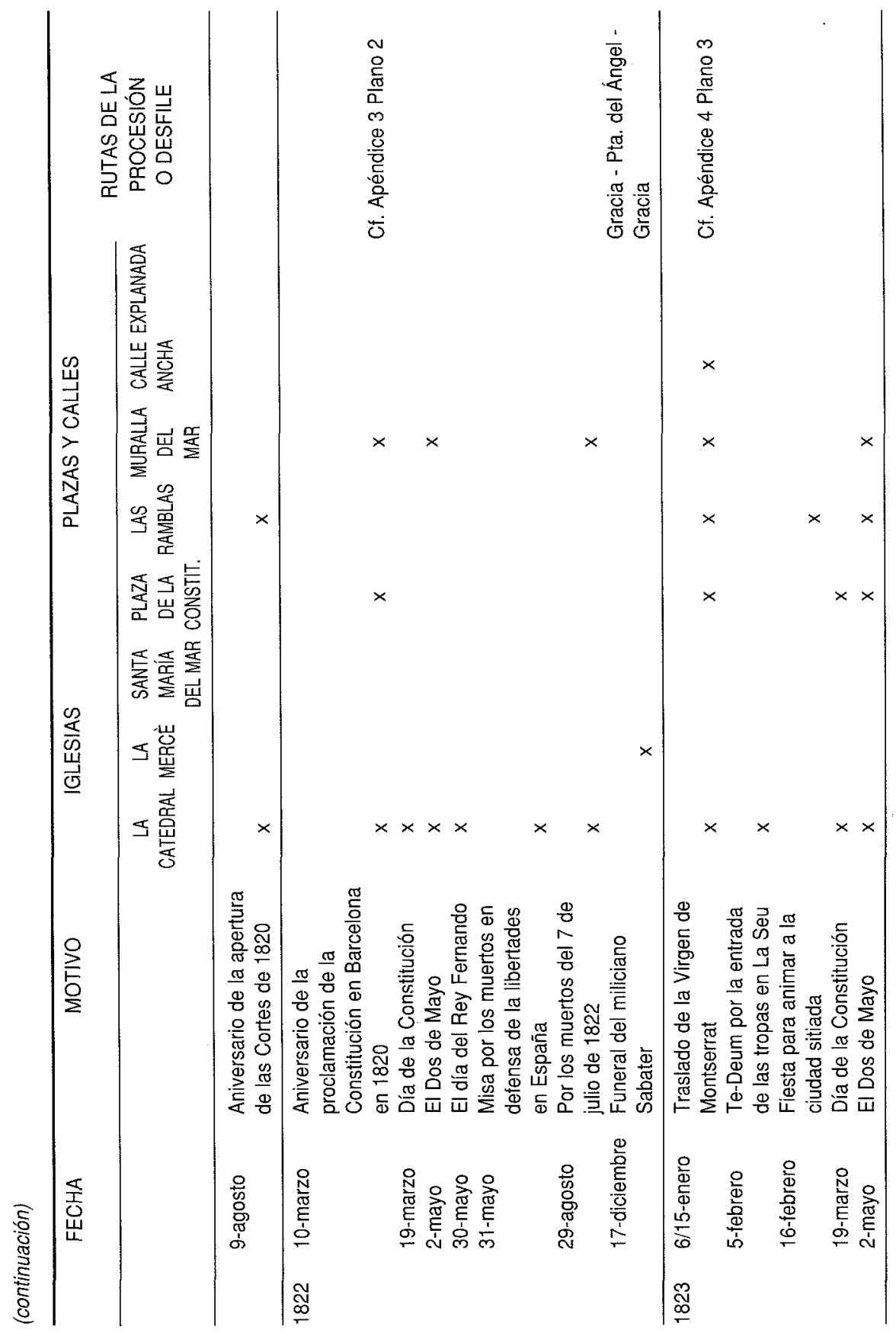




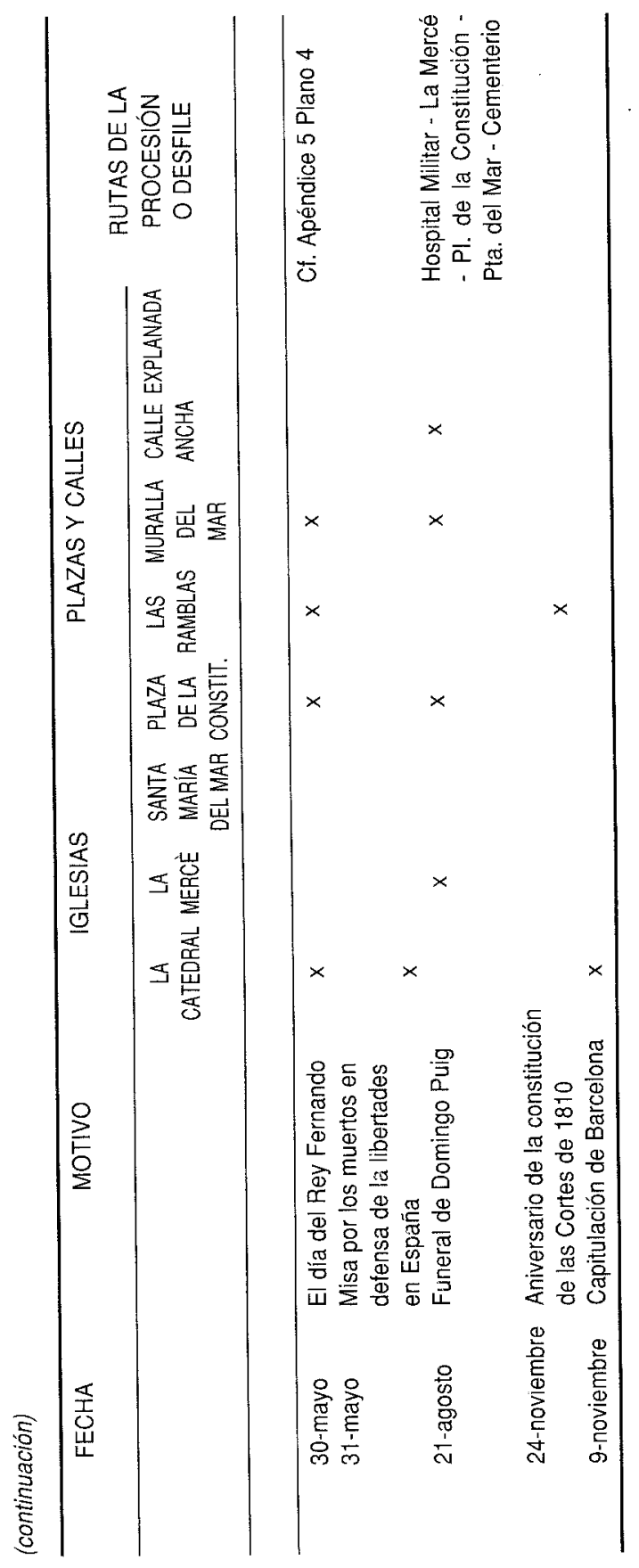


Aunque se sigue advirtiendo la mezcla entre lo religioso y lo civil, el carácter propio de la celebración condicionaba el lugar en que ésta se llevaba a cabo. El principal lugar entre los espacios civiles era La Plaza de la Constitución. Así fue bautizada la antigua Plaza del Palacio cuando se colocó una Lápida de la Constitución el 25 de marzo de $1820^{45}$. Aunque se le cambió el nombre seguía sin ser una plaza de ciudad moderna. En tamaño y en estilo era la misma plaza del Palacio que hubo en el Antiguo Régimen. Si se deseaba celebrar fiestas de gran concurrencia y con actos vistosos, solamente eran posible los desfiles. Además, como el espacio en la ciudad seguía siendo el mismo, sus itinerarios no podían ser otros que los de las procesiones tradicionales. (En los planos adjuntos, hemos señalado los lugares e itinerarios de las principales fiestas liberales - planos 1 a $4-$, y los itinerarios de las procesiones tradicionales - planos 5 y 6-. Cf. Apéndice 2-7).

La autoridad municipal tenía el plan de abrir una plaza más grande, despejada y apta para las celebraciones liberales, con el busto del general Lacy en el centro. Con este motivo, en septiembre de 1822 empezaron a derribar la Puerta del Mar. Sin embargo no parece que este plan llegara a buen fin ${ }^{46}$. Además de ordenar el ya mencionado traslado de las imágenes sagradas situadas en espacios públicos, el 28 de mayo de 1823 se mandó el cambio de los nombres de los baluartes. Esto puede interpretarse como un intento de secularizar y politizar los espacios públicos ${ }^{47}$. De todas maneras, no tuvieron tiempo para todo. Hubo que esperar a la Desamortización general y al derribo de las murallas para que la ciudad tuviera un espacio abierto y secularizado.

\subsection{Frecuencia de las rogativas y otros ritos con causas inesperadas como la epidemia}

Cuando estudiamos la cronología de las fiestas (Apéndice 1), lo que más nos sorprendió fue la gran frecuencia de rogativas y otros ritos cuyas

45 Según CRESPI, «...con gran solemnidad colocaron la Lápida de la Constitución á la galeria de la Lonja frente el Palacio y de hoy adelante la dicha plaza se llamara Plaza de la Constitucion». Diario de Mateu Crespi, 25 de marzo de 1820.

46 Crespi notó el 2 de septiembre de 1822, que «se empezó a derribar la Puerta del Mar para formar una gran plaza que pondrá el busto del General Lacy en el medio». Ibid., 2 de septiembre de 1822.

47 Los nombres nuevos y antiguos de los baluartes eran los siguientes: $1 .^{\circ}$ El Rey Constitucional en lugar del Rey, 2. El Observador en lugar de Santa Madrona, 3. La Libertad en lugar de San Antonio, $4 .^{\circ}$ EI Vigilante en lugar de Tallers, $5 .^{\circ}$ La Constitución en lugar de Canaletas, $6 .^{\circ} \mathrm{La}$ 
causas eran inesperadas como, por ejemplo, una epidemia (celebraciones con el símbolo $h$ ). La epidemia de fiebre amarilla fue un acontecimiento grave y extraordinario. En Barcelona murieron 8.846 personas según una relación de la época ${ }^{48}$. Sin duda los vecinos acudían a cualquier recurso para librarse de la enfermedad. Aparte de establecer un cordón sanitario o de refugiarse lejos de la ciudad -lo cual no era posible para todos- el recurso más útil según la creencia popular eran las rogativas o novenarios. Los médicos no gozaban de la confianza del pueblo ${ }^{49}$.

El domingo dos de septiembre empezaron las rogativas públicas en la Catedral, el nueve empezaron novenarios en la mayor parte de las iglesias de la ciudad, se organizaron también grandes procesiones los días diecinueve y veintiséis de septiembre y el ocho de octubre. Una de ellas se describe así: a los pendones de «ganfarons», bandera de Santa Eulalia y la Cruz de la Catedral, seguían 3.103 individuos (entre adultos y niños) portando cirios, un coro de mercedarios, cuatro beneficiados de cada parroquia y cuatro religiosos de cada convento, la imagen del Santo Cristo de la Purísima Sangre, el Cabildo, la Virgen de las Mercedes bajo palio, el Ayuntamiento, y 176 mujeres vestidas de negro todas portadoras de cirios ${ }^{50}$. Como en todo el recorrido de la procesión pusieron imágenes de Cristo y de la Virgen y se cantaron canciones sagradas, salieron a las ocho de la mañana y no volvieron a la iglesia de la Mercè hasta las doce y media ${ }^{51}$. Incluso fray Serrahima, movido por su devoción dijo: «A pesar de la irregiositat y libertinage que en aquella epoca havia en Barcelona, fou una proffesso tan devota que arrancava llagrimas à quans la miravan (la ortografía es de original) " ${ }^{52}$. No es posible ignorar el fervor con el que se practicaron estos rituales.

El sufrimiento de la ciudad no cesó después de la epidemia. Al año siguiente las rogativas fueron por la sequía. Podemos imaginar que fue una

Ley en lugar de la Puerta del Angel, 7. La España Libre en lugar de Junqueras, $8 .^{\circ}$ El de Cortes, en lugar de San Pedro, 9. ${ }^{\circ}$ La Yndependencia Nacional (baluarte nuevo), 10. La Soberania Nacional en lugar de Puerta Nueva, 11. Lo Invencible en lugar de Medio Día, 12.Atarazanas (el mismo nombre). lbid., 28 de mayo de 1823.

48 La cifra incluye los que murieron en la Barceloneta, que suma 1.272 almas. Altés, Francisco, Sucinta relación de las operaciones del Exmo. Ayuntamiento constitucional de Barcelona del año 1821, Barcelona, 1821, pág. 134. Francisco Altés era secretario del gobierno municipal.

49 Altés anota unos ejemplos de la desconfianza hacia los médicos por parte del pueblo: la existencia de rumores según los cuales los médicos habían esparcido veneno, o el ejemplo de los pacientes que no seguían los consejos del médico y salían a la calle. Ibid., pág. 93, pág. 100.

50 Diario de Mateu Crespi, 8 de octubre de 1821.

51 Ibid. El itinerario de la procesión se ve en el plano (5).

52 Serrahima, Breve Relació..., pág. 238. 
procesión al modo tradicional, basada en la devoción a la Santa Madrona ${ }^{53}$. Según lo que anotó Mateu Crespi el 17 de marzo, fueron muchos los devotos (hombres) que asistieron a la procesión con hachas, y fueron 250 las mujeres que llevaban cirios, muchas de ellas iban descalzas en traje de penitente ${ }^{54}$. Aunque en la "cronología" no se ven tantos símbolos en dichos meses (las $z$ de los días 26 de marzo y 24 de abril significan que en ellos comenzaron las procesiones de rogativas) cada día salió de procesión una parroquia o una comunidad religiosa por turno. Un turno consistía en dieciocho procesiones. Por eso en la primavera del año 1822, se celebraron treinta y nueve procesiones en total. Es curioso que en los años que siguieron a la caída del régimen liberal, en 1824 y 1825, se efectuaron rogativas por la sequía de la misma manera que en el $1822{ }^{55}$. Esto muestra la existencia de una conducta popular que persistía igual a pesar de los cambios de régimen. Como hemos señalado anteriormente, en esas rogativas vemos el ansia del pueblo por continuar con los ritos tradicionales.

\section{A MODO DE CONCLUCIÓN}

Ozouf señala en su obra sobre las fiestas revolucionarias de la Revolución Francesa que cada pueblo tiene mitos y fiestas que se podrían convertir en germen eficaz de la solidaridad, si de ellos se eliminara «lo irracional». Los liberales españoles del Trienio Constitucional organizaron muchas fiestas. En cuanto a las fiestas liberales de Barcelona, el hecho de que la mayoría de sus símbolos fueran nuevos y tuvieran carácter político muestra el propósito de los dirigentes liberales de utilizar las fiestas como "escuela" para instruir al pueblo ${ }^{56}$. La importancia que tenían la religión o las ceremonias religiosas se debía, posiblemente, al carácter del liberalismo español del primer tercio del siglo, que no había superado el regalismo de los ilustrados y que buscaba la oportunidad de establecer una Iglesia Liberal en España. Al mismo tiempo, se constata el dilema de los radicales que no podían desprenderse del culto católico para no alejarse del pueblo.

53 Santa barcelonesa, una de las patronas de la ciudad. Con ocasión de la sequía, su tumba fue visitada por una procesión solemne y su cuerpo fue llevado a la Catedral. ALMERIC, Tradicions, festes $i$ costums..., págs. 32-33.

54 También anotó que eran las ocho de la noche cuando regresó a la iglesia siendo las nueve cuando entró en la capilla. Diario de Mateu Crespi, 18 de marzo de 1822.

55 lbid., 29 de marzo de 1824 y ss., 21 de febrero de 1825 y ss., y 29 de junio de 1825.

56 Ozouf, Mona, "L'histoire de la fête révolutionaire», en La fête révolutionaire 1789-1799, París, 1976. Consultamos la versión japonesa de sus obras traducidas por Koichi Tachikawa, Tokio, 1988. 
Incluso en las grandes ciudades como Barcelona, aun apoyando con fervor al régimen liberal, el pueblo se mostraba reacio a abandonar el culto tradicional.

En las fiestas de Barcelona de dicho período también advertimos otras características incompatibles con el liberalismo centralista: Ia tendencia romanticista -en especial de los dirigentes liberales moderados- y el ansia del pueblo por continuar con los símbolos tradicionales. Durante el Trienio los propios liberales no eran conscientes de estas contradicciones. Sin embargo, las ideas de "nación» o «patria" pronto se convirtieron en temas de discusión.

Aunque no lo hemos podido estudiar bien en este trabajo, se aprecian nuevas características en cuanto a la organización de las fiestas. Son ejemplos la participación de las mujeres, aunque fuera limitada, y la desaparición, especialmente después de la epidemia del año 1821, de los gremios y colegios como organizadores de las fiestas. En cambio, se ve claramente que los batallones de la Milicia Nacional, tanto Voluntaria como Legal, tomaban parte activa en las fiestas. En cuanto a los lugares de celebración de las fiestas también advertimos una característica nueva: la intención de los liberales - sobre todo de los radicales que detentaron el poder municipal durante el último año del trienio- de crear espacios nuevos y laicos para sus celebraciones. Sin embargo, sus planes no llegaron a dar fruto.

En resumen, durante los cuatro años de intensa experiencia del liberalismo se celebraron muchas fiestas para animar e instruir al pueblo. Sin embargo, tenemos la impresión de que hubo que esperar hasta el republicanismo o el catalanismo del último tercio del siglo para que los barceloneses tuvieran un culto común y popular que no fuera el católico. Un culto que concentrara tanto el deseo de cambio político y social como los símbolos tradicionales y populares. En relación con las fiestas liberales de la Barcelona del Trienio, tenemos la intención de continuar nuestros estudios para aclarar las diferencias de mentalidad y cultura entre los distintos estratos liberales y populares, así como sus contradicciones internas. 


\section{Apéndice 1}

Cronología de las fiestas y celebraciones cívico-religiosas en la Barcelona Constitucional (1820-1823) según el Diario de Mateu Crespi

Símbolos utilizados

0 Fiestas o celebraciones religiosas

(9) Fiestas liberales celebradas con algún ritual religioso

Traslado de reliquias o estatuas religiosas por orden de la autoridad liberal

Funerales de milicianos o soldados liberales

- Fiestas seculares

$\$$ Rogativas o celebraciones por causas inesperadas: una epidemia, por ejemplo

$X$ Fecha de las fiestas no mencionadas

Fiestas o celebraciones de alguna comunidad en particular

1820

25-marzo

2-abril

Q 2-mayo

(6) 21-mayo

(1-junio

24-junio

O29-junio

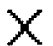

(6)

1-julio

2-julio

(o)

2-julio

4-julio

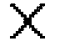

(6) 5/6-julio

(Q) 13/15-julio

th

(o)

6-agosto

(6)
Juramento de la Constitución

Pascua

El Dos de Mayo

Elecciones

Corpus Christi

San Juan

San Pedro

Apertura de las Cortes

Bendición de la bandera del 1r. batallón de la MNV

Empiezan novenarios por la epidemia

Funeral del general Lacy

Publicación del juramento de la Constitución por el Rey

Bendición de la bandera del $2 .^{\circ}$ batallón de la MNV.

Bendición de la bandera del $3 .^{\circ}$ batallón de la MNV 


\section{Apéndice 1 (continuación)}

Cronología de las fiestas y celebraciones cívico-religiosas en la Barcelona Constitucional (1820-1823) según el Diario de Mateu Crespi

\begin{tabular}{|c|c|}
\hline 18/20-septiembre & Misas de los trinitarios descalzos \\
\hline 24-septiembre & Aniversario de la constitución de las Cortes de 1810 \\
\hline 2-octubre & Mercè (en lugar del 24 de sept.) \\
\hline 31-octubre & Inauguración de la Capilla del Campo Santo \\
\hline 24/26-noviembre & Se celebra el descubrimiento de una conspiración en Madrid \\
\hline$\omega^{\text {2-diciembre }}$ & Misa para celebrar el descubrimiento de la conspiración \\
\hline 1821 & \\
\hline $6^{14-e n e r o}$ & Bendición de la bandera del $4 .^{\circ}$ batallón de la MNV \\
\hline 24-enero & Traslado de las reliquias \\
\hline 12-febrero & Misa a la patrona Santa Eulalia por el $3 .^{\circ}$ batallón de la MNV \\
\hline O7-marzo & Miércoles de Ceniza \\
\hline (6) 10/11-marzo & Aniversario de la proclamación de la Constitución en Barcelona \\
\hline (6) 19-marzo & Día de la Constitución \\
\hline O15-abril & Domingo de Ramos \\
\hline$X 22$-abril & Pascua \\
\hline (9) 2-mayo & El Dos de Mayo \\
\hline (6) 30-mayo & El día del Rey Fernando \\
\hline (9) 1-junio & $\begin{array}{l}\text { Misa porlos muertos en defensa de las libertades en España (en } \\
\text { lugar del } 31 \text { de mayo }\end{array}$ \\
\hline $\bar{y}^{19-j u n i o}$ & Funeral por ocho soldados fusilados por los realistas \\
\hline$Q_{21 \text {-junio }}$ & Corpus Christi \\
\hline 29-junio & Traslado de la Vírgen \\
\hline (9) 9-julio & Aniversario de la apertura de las Cortes del 1820 \\
\hline
\end{tabular}




\section{Apéndice 1 (continuación)}

Cronología de las fiestas y celebraciones cívico-religiosas en la Barcelona Constitucional (1820-1823) según el Diario de Mateu Crespi

\begin{tabular}{|c|c|}
\hline 15-julio & Regata de barcas \\
\hline Kreptiembre & Empiezan las rogativas públicas en la Catedral (hasta el 26 de nov.) \\
\hline K 11-septiembre & Empiezan novenarios en la mayor parte de las iglesias \\
\hline X 19-septiembre & Procesión de rogativas \\
\hline 26-septiembre & Procesión de rogativas \\
\hline H 8-octubre & Procesión de rogativas \\
\hline 24-octubre & Quedaron suspensas todas las celebraciones salvo las rogativas \\
\hline 25-octubre & Te Deum en la Barceloneta \\
\hline 25-noviembre & Te Deum \\
\hline th 19-diciembre & Funeral por todos los muertos durante la epidemia \\
\hline \multicolumn{2}{|l|}{1822} \\
\hline 7-enero & Recibimiento del Regimiento de Córdoba \\
\hline 12-enero & Recibimiento del General Riego \\
\hline O13-enero & Procesión de la Bula de la Santa Cruzada \\
\hline $\begin{array}{l}\text { t11,13,14, } \\
\text { 28-enero }\end{array}$ & $\begin{array}{l}\text { Funerales por los batallones de la MNV por sus miembros } \\
\text { muertos en la epidemia }\end{array}$ \\
\hline $\mathrm{Q}^{12 \text {-febrero }}$ & Santa Eulalia \\
\hline O20-febrero & Miércoles de Ceniza \\
\hline (6) 10-marzo & Aniv. de la proclamación de la Constitución en Barcelona \\
\hline 17-marzo & Procesión de rogaiivas por la sequía \\
\hline 6 19-marzo $^{-19}$ & Día de la Constitución \\
\hline K 25-marzo & Procesión de rogativas \\
\hline 3 26-marzo & $\begin{array}{l}\text { Empieza el } 1 .^{\circ} \text { turno de las procesiones de rogativas (hasta el } 16 \text { de } \\
\text { abril salvo los días } 2 \text { y } 5 \text { ) }\end{array}$ \\
\hline$O_{2 / 5}$-abril & Semana Santa (sin procesiones) \\
\hline 24-abril & $\begin{array}{l}\text { Empieza el segundo turno de las procesiones de rogativas (hasta el } \\
13 \text { de mayo salvo los días } 2 \text { y } 3 \text { ) }\end{array}$ \\
\hline 6 2-mayo & El Dos de Mayo \\
\hline
\end{tabular}




\section{Apéndice 1 (continuación)}

Cronología de las fiestas y celebraciones cívico-religiosas en la Barcelona Constitucional (1820-1823) según el Diario de Mateu Crespi

\begin{tabular}{|c|c|}
\hline 17-mayo & Retorno de las reliquias de Santa Madrona \\
\hline (6) 30-mayo & El día del Rey Fernando \\
\hline (6) 31-mayo & Misa por los muertos en defensa de las libertades en España \\
\hline 6-junio & Corpus Christi \\
\hline 23-julio & Declaración del estado de guerra en Cataluña \\
\hline 29-agosto & Misa por los muertos del 7 de julio \\
\hline 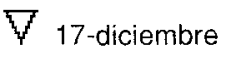 & Funeral del miliciano Sabater \\
\hline \multicolumn{2}{|l|}{1823} \\
\hline 6/15-enero & Traslado de la Vírgen de Montserrat \\
\hline (6) 5-febrero & Te Deum por la entrada de las tropas en La Seu \\
\hline 12-febrero & Miércoles de Ceniza \\
\hline 16 -febrero & Fiesta para animar a los ciudadanos \\
\hline 3-marzo & Traslado de la imagen de El Pilar \\
\hline$(9)^{9-m a r z o}$ & Bendición de la bandera del escuadrón de caballería de la MV \\
\hline 6) 19-marzo & Día de la Constitución \\
\hline 30-marzo & Pascua \\
\hline 6 -abril & $\begin{array}{l}\text { Bendición de la insignia de León de los batallones } 6 \text { de la MV } \\
\text { y } 7 \text { y } 11 \text { de la Milicia Legal }\end{array}$ \\
\hline (9) 2-mayo & El Dos de Mayo \\
\hline O29-mayo & Corpus Christi \\
\hline 6 30-mayo & El día del Rey Fernando \\
\hline (6) 31-mayo & Misa por los muertos en defensa de la libertad española \\
\hline $\bar{y}^{21-j u l i o}$ & Funeral del miliciano Domingo Puig \\
\hline$y^{1-a g o s t o}$ & Funeral por los muertos en la acción del día 30 \\
\hline 24-septiembre & Aniversario de la constitución de las Cortes de 1810 \\
\hline 1-noviembre & CAPITULACIÓN DE BARCELONA \\
\hline 9-noviembre & Misa y Te Deum para celebrarla \\
\hline
\end{tabular}


Fiestas y celebraciones cívico-religiosas en la Barcelona constitucional (1820-1823)

\section{Apéndice 2}

Plano 1. Funeral de Lacy (6 de julio de 1820)

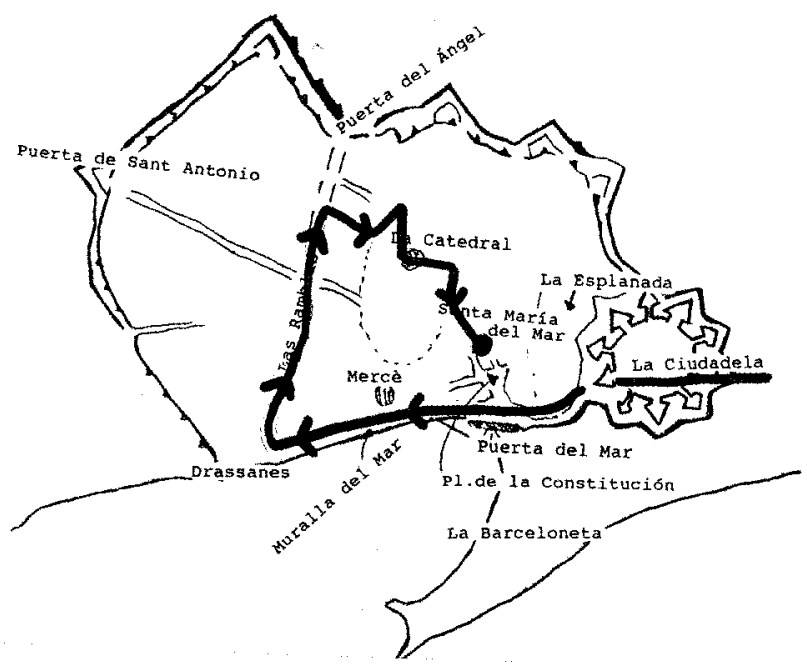

Apéndice 3

Plano 2. Aniversario de la proclamación de la Constitución en Barcelona en 1820 ( 11 de marzo de 1821 y 10 de marzo de 1822)

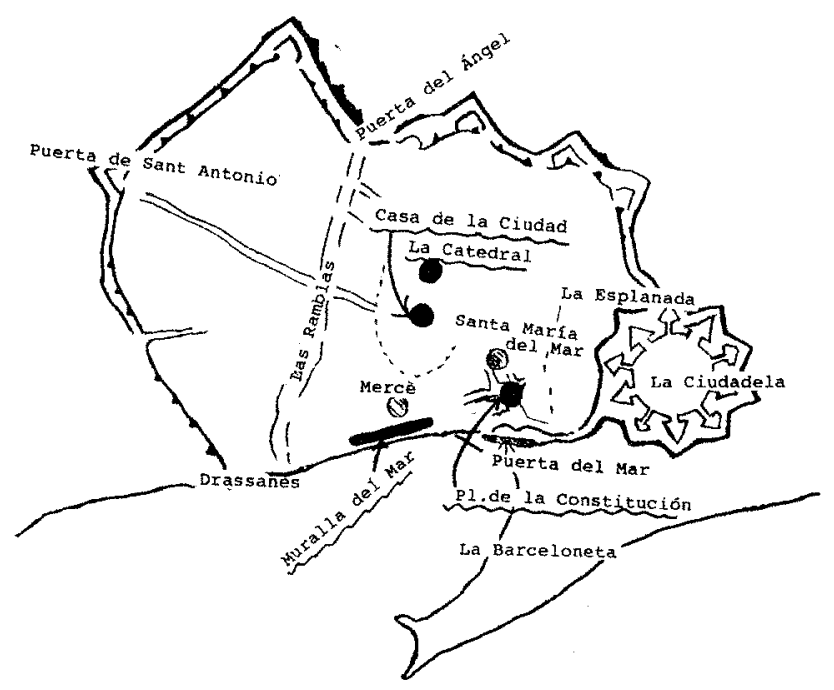




\section{Apéndice 4}

Plano 3. Traslado de la Virgen de Montserrat (6 de enero de 1823)

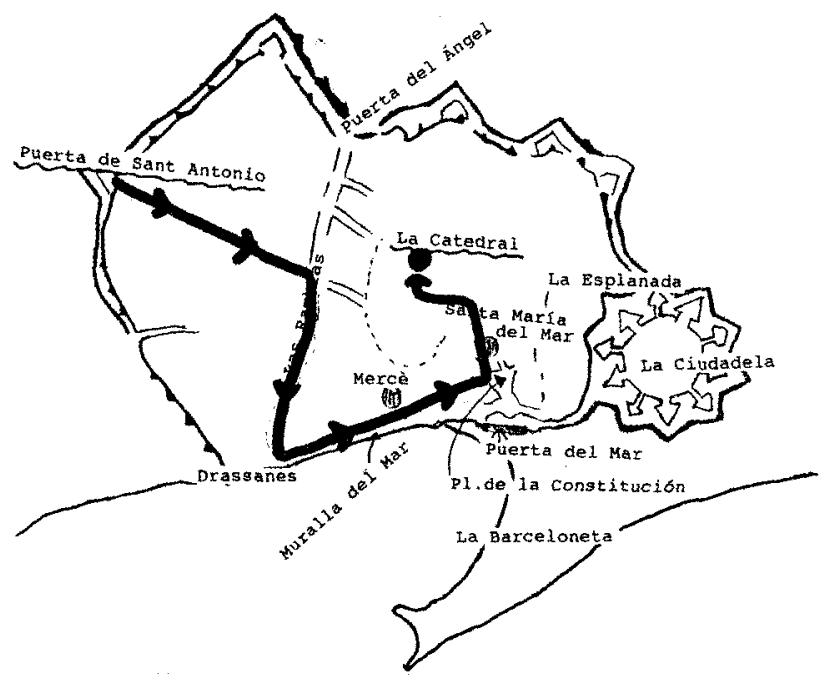

\section{Apéndice 5}

Plano 4. El Día del Rey Fernando (30 de mayo de 1823)

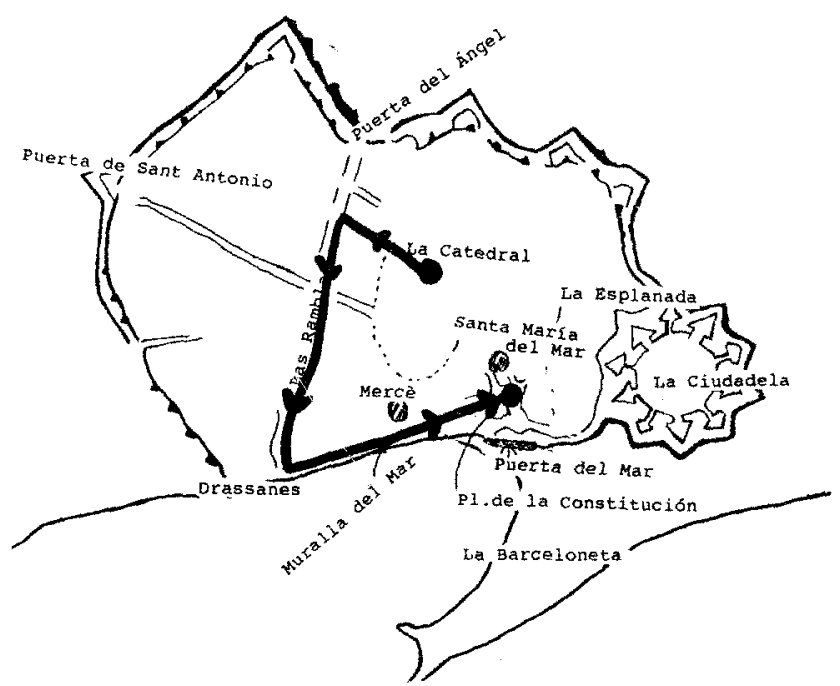




\section{Apéndice 6}

Plano 5. Procesión de Rogativas con motivo de la epidemia ( 8 de octubre de 1821)

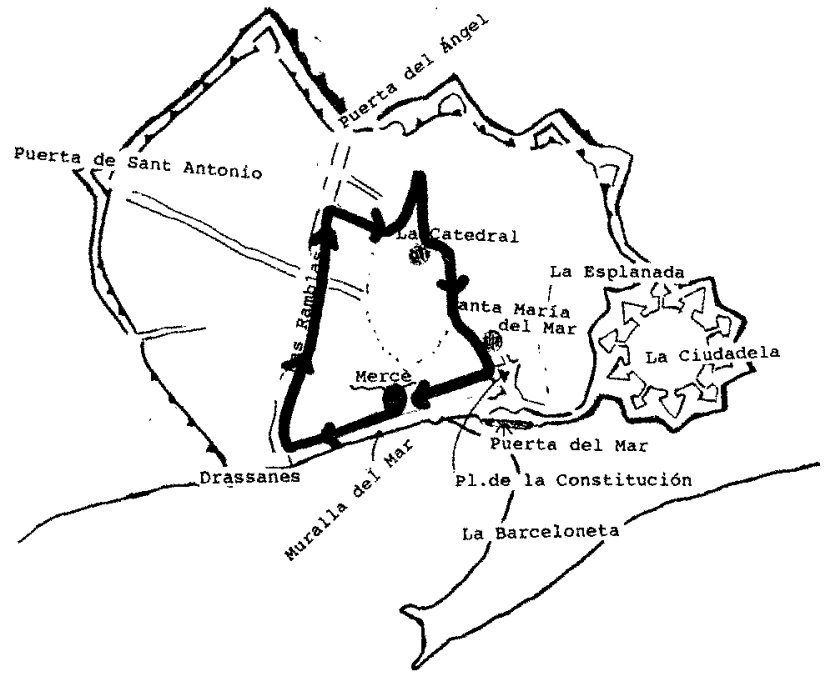

\section{Apéndice 7}

Plano 6. Procesión del Corpus Christi (29 de mayo de 1823)

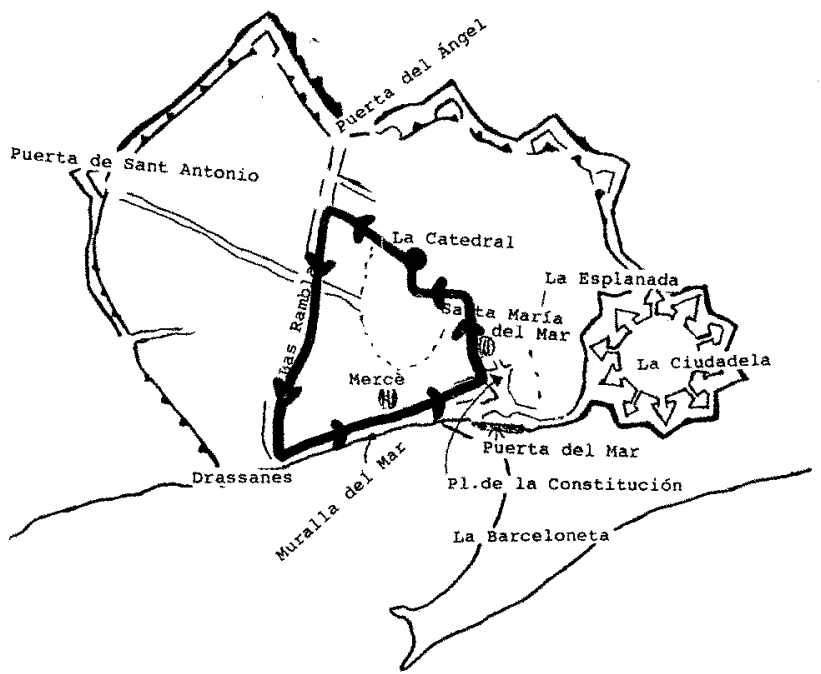

